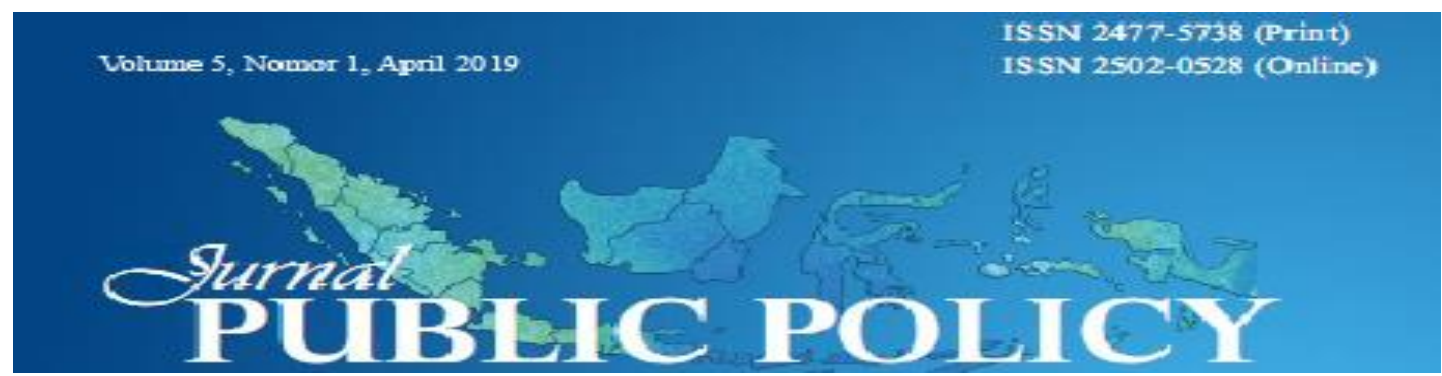

Journal homepage: http//:jurnal.utu.ac.id/jppolicy

\title{
STRATEGI PANGLIMA LAOT DALAM MENCEGAH ILLEGAL FISHING DI KABUPATEN ACEH BARAT
}

\author{
Nodi Marefanda ${ }^{1}$ Afrizal Tjoetra ${ }^{2}$ \\ ${ }^{1,2}$ Fakultas Ilmu Sosial dan Ilmu Politik, Universitas Teuku Umar \\ nodimarefanda@utu.ac.id \\ afrizaltjoetra@utu.ac.id
}

\begin{abstract}
Abstrak
Illegal fishing sangat melemahkan pengelolaan sumber daya perikanan, sehingga negara wajib mendukung pemberantasannya. Salah satu lembaga adat yang juga konsentrasi dalam pemberantasan kegiatan Illegal fishing tersebut adalah lembaga panglima laot. Adapun tujuan utama dalam penelitian ini adalah untuk mengetahui strategi lembaga panglima laot dalam mencegah illegal fishing di Kabupaten Aceh Barat. Target khusus yang ingin dicapai adalah terdapatnya data aktual yang selanjutnya dinarasikan secara histroris dan empiris terkait strategi kelembagaan panglima laot. Sedangkan metode yang digunakan dalam penelitian ini adalah deskriptif kualitatif. Teknik penentuan informan menggunakan teknik non probability sampling dengan cara purposive sampling, hal ini karena dalam penelitian kualitatif penentuan informan tidak untuk mewakili populasi tetapi melihat kedalaman data, sehingga diperlukan keahlian informan dalam permasalahan yang menjadi kajian dalam penelitian. Berdasarkan hal tersebut, maka informan yang digunakan dalam penelitian ini ditentukan berdasarkan tujuan atau pertimbangan tertentu peneliti. Hasil penelitian yang telah dilakukan, ditemukan data bahwa strategi yang dilakukan kelembagaan panglima laot dalam mencegah illegal fishing di aceh barat yaitu: "Membentuk kelembagaan panglima laot di tingkat lhok, Penguatan kelembagaan panglima laot di tingkat lhok, Menjalin kerjasama dengan berbagai stakeholder, Pelarangan penggunaan alat tangkap yang tidak ramah lingkungan" dan penerapan strategi tersebut terlihat belum efektif dilakukan.
\end{abstract}

\section{Kata Kunci: Aceh Barat, Efektivitas, Panglima Laot.}




\section{PENDAHULUAN}

Salah satu kabupaten yang menjadi sasaran praktik kegiatan illegal fishing adalah Kabupaten Aceh Barat, dimana Aceh Barat berada di perairan Samudera Hindia yang menyimpan banyak potensi sumber daya laut dan perikanan yang begitu besar. Praktik illegal fishing jelas meresahkan masyarakat, khususnya nelayan lokal. Aksi pencurian ikan oleh nelayan asing yang menggunakan kapal besar dengan fasilitas modern telah berdampak merugikan keberadaan nelayan lokal karena digunakannya alat tangkap jaring jenis trawl yang berpengaruh pada berkurangnya hasil tangkapan nelayan lokal. Hal ini dibuktikan dengan adanya salah satu kasus yang sempat di sorot oleh media online (2014) yang mengatakan bahwa empat kapal ikan Thailand dan Burma ditangkap aparat gabungan TNIPolri di perairan Kabupaten Aceh Barat, 12 mil dari bibir pantai Meulaboh dan mengamankan 60 anak buah kapal serta puluhan ton ikan hasil tangkapan serta mengamankan empat kapal motor dengan kapasitas 40 Gross Ton (GT) dengan menggunakan alat tangkap pukat harimau yang dapat merusak ekosistem laut seperti terumbu karang serta meresahkan nelayan lokal (Metrotvnews.com).

Praktik illegal fishing tidak hanya dilakukan oleh nelayan asing saja, nelayan luar daerah bahkan nelayan lokal pun turut andil dalam praktik tersebut, modus yang sering dilakukan yaitu menggunakan alat penangkapan ikan yang tidak sesuai dengan ketentuan. Seperti contoh kasus yang terjadi di perairan Samatiga dan Arongan Lambalek kabupaten Aceh barat, para nelayan menangkap delapan unit boat karena menggunakan alat tangkap pukat trawl untuk menangkap ikan di wilayah perairan Samatiga dan Arongan Lambalek. Sebagaimana yang diungkapkan oleh panglima laot Aceh Barat Amiruddin dalam berita Serambi Indonesia (2017) mengatakan bahwa

Kegiatan illegal fishing yang umum terjadi di perairan Kabupaten Aceh Barat adalah penangkapan ikan dengan menggunakan alat tangkap terlarang yaitu trawl. Aksi illegal fishing tersebut di tandai dengan tertangkapnya kapal perikanan tangkap di perairan Kabupaten Aceh barat yang dapat dilihat pada Tabel 1 berikut.

Tabel 1 Jumlah Kasus Illegal Fishing Tahun 2014-2017

\begin{tabular}{|c|c|c|c|}
\hline No & Tahun & Jumlah Kasus & Keterangan \\
\hline 1 & 2014 & 4 & - \\
\hline 2 & 2015 & - & Pembinaan \\
\hline 3 & 2016 & - & Pembinaan \\
\hline 4 & 2017 & 6 & - \\
\hline
\end{tabular}

(Sumber: Satuan Polisi Perairan Aceh Barat 2014-2017; diolah kembali)

Jumlah kasus yang terjadi pada tahun 2014 yaitu 4 kasus illegal fishing. Pada tahun 2015 dan 2016 tidak dilakukan penangkapan terhadap pelaku illegal fishing, melainkan hanya dilakukan pembinaan. Pembinaan tersebut meliputi peringatan dan pendampingan kepada masyarakat nelayan mengenai pergantian alat tangkap yang ramah lingkungan serta memberikan pemahaman tentang pentingnya menjaga kelestarian laut. Meskipun telah di lakukan pembinaan terhadap masyarakat nelayan, pada tahun 2017 kasus illegal fishing kembali mengalami kenaikan menjadi 6 kasus.

Panglima Laot merupakan salah suatu institusi adat yang mengatur tentang tata cara meupayang atau penangkapan ikan di laut. panglima laot selain sebagai institusi juga sebagai seorang ketua lembaga itu sehingga orang menyebut mereka sebagai panglima laot. Menurut sejarahnya kelembagaan panglima laot telah ada sejak 400 tahun yang lalu, yaitu pada masa pemerintahan Sultan Iskandar Muda (1607-1636) yang memerintah kerajaan Islam Aceh. 
Saat itu tugas panglima laot adalah: Pertama, memungut cukai pada kapal-kapal yang singgah di pelabuhan dan, Kedua, memobilisasi rakyat terutama nelayan untuk berperang.

Pasca Tsunami 24 Desember 2004, tahun 2006 Panglima Laot mendapat pengakuan Undang-undang No 11 tahun 2006 tentang Pemerintahan Aceh (pasal 98 - 99 dan pasal 162 ayat (2) huruf e), kemudian Undang-undang tersebut dijabarkan kedalam Qanun Aceh No. 9 Tahun 2008 tentang Pembinaan Kehidupan Adat dan Adat Istiadat dan Qanun Aceh No. 10 tahun 2008 tentang Lembaga Adat. Pada tahun yang sama Panglima Laot diterima menjadi anggota World fisher forum people (WFFP) pada tahun 2008.

Panglima Laot juga memiliki aturan bahwa para nelayan dilarang melakukan pemboman, peracunan, pembiusan, penglistrikan, pengambilan terumbu karang, dan bahanbahan lainnya yang dapat merusak lingkungan hidup dan biota lainnya. Selain itu, sejak dulu Lembaga Hukum Adat Laot telah berperan aktif dalam rangka mencegah terjadi illegal fishing (penangkapan ikan secara ilegal). Hal ini dapat dilihat, misalnya: Panglima Laot Melaporkan Aksi Pencurian Ikan Oleh 40 Kapal Thailand pada Tahun 2000 (PW. Yusuf Sulaiman, 2009). Peran kelembagaan Panglima Laot sangat penting didalam kehidupan nelayan baik dalam mensejahterakan maupun dalam mencegah illegal fishing. Sebab potensi ikan di perairan laut Aceh Pada tahun 2014 diperkirakan mencapai 1,8 juta ton/tahun. Namun yang selama ini kita hasilkan baru sebesar 170 ribu ton/tahun. Produksi ikan laut yang kita dapatkan selama ini hanya baru 10 persen dari potensi yang ada. Banyak potensi lain yang belum tergarap. (Gubernur Aceh, 2014). Panglima Laot Aceh juga berfungsi sebagai unsur penghubung antara pemerintah dan masyarakat nelayan serta sebagai pembantu pemerintah dalam menyukseskan program pembangunan perikanan dan kelautan dan program-program pemerintah lainnya. Berangkat dari latar belakang yang telah dipaparkan tersebut, artikel ini membahas hasil penelitian tentang strategi panglima laot dalam mencegah illegal fishing di kabupaten aceh barat.

\section{METODE PENELITIAN}

\section{Tempat dan Waktu Penelitian.}

Penelitian Strategi Kelembagaan Panglima Laot dalam mencegah Illegal Fishing di Kabupaten Aceh Barat dilakukan dengan durasi waktu kurang lebih 3 bulan.

\section{Metode Penelitian}

Metode penelitian yang digunakan pada penelitian ini adalah metode deskriptif dengan pendekatan kualitatif.

\section{Teknik Penentuan Informan.}

Teknik penentuan informan dalam penelitian dengan menggunakan purposive sampling yaitu menentukan informan dengan asumsi bahwa informan tersebut sangat paham dengan permasalahan yang sedang diteliti. Adapun informan pada penelitian tersebut adalah:
a. Panglima Laot Kabupaten Aceh Barat;
1 Orang
b. Panglima laot lhok
5 orang
c. Dinas Kelautan dan Perikanan
1 orang
d. Nelayan
8 orang
e. TNI AL
1 orang 


\section{Teknik Pengumpulan Data}

Penelitian Strategi Kelembagaan Panglima Laot Dalam Mencegah Illegal, Unreported, Unregulated Fishing Di Kabupaten Aceh Barat yang dilakukan bersifat deskriptif kualitatif. Sumber data primer adalah peneliti yang melakukan tindakan dan informan yang menerima tindakan, sedangkan data skunder yang berupa data dokumentasi. Pengambilan data dilakukan dengan teknik observasi, wawancara dan dokumentasi.
a. Observasi
b. Wawancara
c. Dokumentasi

Untuk menjamin data yang diterima cukup kredibel, maka peneliti menggunakan sistem triangulasi. Sugiyono (2008:125) menyatakan bahwa triangulasi dalam pengujian kredibilitas ini diartikan sebagai pengecekan data dari berbagai sumber dengan berbagai cara dan berbagai waktu, sehingga triangulasi dapat dikelompokkan dalam tiga jenis, yaitu triangulasi sumber data, triangulasi teknik pengumpulan data dan waktu pengumpulan data.
a. Triangulasi Sumber
b. Triangulasi Teknik
c. Triangulasi Waktu

\section{Teknik Analisis dan Uji Keabsahan Data.}

Teknik analisis data yang digunakan dalam penelitian ini adalah menggunakan langkah-langkah seperti yang dikemukakan oleh Burhan Bungin (2009), yaitu sebagai berikut:

1. Pengumpulan Data (Data Collection)

2. Reduksi Data (Data Reduction)

3. Display Data

4. Verifikasi dan Penegasan Kesimpulan (Conclution Drawing and Verification) Antara display data dan penarikan kesimpulan terdapat aktivitas analisis data yang ada. Dalam pengertian ini analisis data kualitatif merupakan upaya berlanjut, berulang dan terusmenerus. Masalah reduksi data, penyajian data dan penarikan kesimpulan/verifikasi menjadi gambaran keberhasilan secara berurutan sebagai rangkaian kegiatan analisis yang terkait. Selanjutnya data yang telah dianalisis, dijelaskan dan dimaknai dalam bentuk kata-kata untuk mendeskripsikan fakta yang ada di lapangan, pemaknaan atau untuk menjawab pertanyaan penelitian yang kemudian diambil intisarinya saja.

\section{HASIL DAN PEMBAHASAN}

\section{Strategi Kelembagaan Panglima Laot dalam Mencegah Illegal Fishing.}

Strategi Kelembagaan Panglima laot dalam pencegahan illegal fishing di Kabupaten Aceh Barat yaitu:

\section{Membentuk kelembagaan panglima laot di tingkat lhok}

Pada dasarnya Keputusan Gubernur Aceh Nomor: 523.11/012/2005 (tertanggal 8 Maret 2005), dengan jelas menyebutkan bahwa mengukuhkan panglima laot di lakukan dalam rangka menyukseskan pembangunan subsektor perikanan, dengan tugas dan wewenang dalam kedudukannya sesuai adat membantu tugas pemerintah dalam pembangunan bidang sub sektor perikanan dan masyarakat nelayan dalam arti luas. Adapun tugas utama panglima laot ada 8 yaitu: melaksanakan, memelihara dan mengawasi pelaksanaan adat istiadat dan hukum adat laot, membantu Pemerintah dalam bidang perikanan dan kelautan, 
menyelesaikan sengketa dan perselisihan yang terjadi diantara nelayan sesuai dengan ketentuan hukum adat laot, menjaga dan melestarikan fungsi lingkungan kawasan pesisir dan laut, memperjuangkan peningkatan taraf hidup masyarakat nelayan, mencegah terjadinya penangkapan ikan secara illegal, memberikan advokasi kebijakan kelautan dan perikanan serta memberikan bantuan hukum kepada nelayan yang terdampar di negara lain dan mengkoordinasikan pelaksanaan hukum adat laot.

Hasil penelitian diperoleh data bahwa Kabupaten Aceh Barat memiliki 22 lhok dengan jumlah nelayan setiap lhok berbeda-beda dan mayoritas nelayan berasal dari kecamatan johan pahlawan. Untuk melancarkan tugas yang diemban panglima laot Kabupaten Aceh Barat, maka panglima laot membentuk panglima laot di tingkat lhok agar dapat melancarkan tugas dan tanggungjawab. Adapun panglima laot lhok di Kabupaten Aceh Barat berjumlah 10 panglima laot lhok yang berada di lhok langung, lhok meureubo, lhok suak ribe, lhok panggung, lhok kuala bubon, lhok bubon, lhok suak smase, lhok meurebo, lhok cot kumbang dan lhok suak ule.

\section{Penguatan kelembagaan panglima laot di tingkat lhok}

Penguatan kelembagaan panglima laot di tingkat lhok menjadi penting untuk memastikan perannya dalam melakukan pencegahan illegal fishing sebagaimana tugas pokok panglima laot. Hal ini dirasakan kurangnya pendampingan terhadap pelaksanaan fungsi panglima laot lhok. Kondisi tersebut memberi dampak negatif terhadap optimalisasi pencegahan illegal fishing di wilayah pesisir kabupaten aceh barat.

\section{Membentuk Kelompok masyarakat pengawas (POKMASWAS)}

POKMASWAS adalah sekelompok masyarakat yang melakukan pengawasan terhadap berlangsungnya pemanfaatan sumber daya kelautan dan perikanan. Sesuai dengan KEPMEN No 58 Tahun 2001, POKMASWAS merupakan pelaksana pengawasan di tingkat lapangan yang terdiri dari unsur tokoh masyarakat, tokoh agama, tokoh adat, LSM, nelayan, petani ikan serta masyarakat maritim lainnya. Pembentukannya berawal dari inisiatif masyarakat yang difasilitasi oleh unsur pemerintah daerah, dan dikoordinir oleh seorang anggota masyarakat dalam POKMASWAS, yang berfungsi sekaligus sebagai mediator antara masyarakat dengan pemerintah/petugas.

Tugas POKMASWAS hanyalah mengamati atau memantau (melihat, mendengar) kegiatan perikanan dan pemanfaatan lingkungan yang ada di daerahnya, kemudian melaporkan adanya dugaan pelanggaran terhadap peraturan perundang-undangan perikanan atau dugaan tindak pidana dibidang perikanan kepada Pengawas Perikanan atau aparat penegak hukum. Dalam menjalankan tugasnya, POKMAWAS dapat berhubungan langsung baik kepada panglima laot, dinas kelautan dan perikanan hingga sampai pada kementerian kelautan dan perikanan melalui fasilitas SMS Gatway yang memang diberikan oleh dinas keluatan dan perikanan melalui kerjasama dengan panglima laot

POKMASWAS di Kabupaten Aceh Barat dibentuk dengan beranggotakan 10 orang yang berasal dari unsur nelayan dan pembentukannya dilakukan melalui musyawarah dan mufakat oleh setiap nelayan. POKMASWAS di Kabupaten Aceh Barat berada di tiga lokasi yaitu: 


\begin{tabular}{|c|l|c|c|}
\hline No & \multicolumn{1}{|c|}{ POKMASWAS } & Jumlah anggota & Keterangan \\
\hline 1 & Arongan lambalek & 10 orang & Aktif \\
\hline 2 & Johan Pahlawan & 10 orang & Aktif \\
\hline 3 & Suak semasih & 10 orang & Aktif \\
\hline
\end{tabular}

Pembentukan dan penentuan lokasi pembentukan POKMASWAS tersebut didasarkan atas pertimbangan banyaknya kasus illegas fishing dan masih belum teratasi sehingga pemerintah menginisiasi untuk membentuk di daerah tersebut dengan harapan dapat menjalankan fungsinya dengan baik yaitu melakukan pelaporan jika terjadi pelanggaran/permasalahan dalam pengelolaan dan penangkapan ikan.

\section{Menjalin kerjasama dengan berbagai stakeholder}

Salah satu strategi yang dilakukan panglima laot kabupaten aceh barat selama ini menjalin hubungan kerjasama dengan berbagai instansi seperti angkatan laot, polisi air dan dinas kelautan dan perikanan. Kerjasama yang dijalin tersebut bertujuan untuk memaksimalkan peran dan fungsi serta dukungan terhadap keberhasilan dalam pencegahan illegal fishing yang selama ini sering terjadi di wilayah perairan kabupaten aceh barat.

Selama ini telah disepakati oleh kelembagaan panglima laot, DKP, TNI AL dan Polair jika terjadi penangkapan ikan dengan alat tangkap trawl atau semi trawl maka konsekuensinya jika nelayan tersebut tertangkap yaitu penyitaan terhadap alat tangkap yang digunakan serta setelah disita alat tangkap tersebut dimusnahkan dengan cara dibakar, walaupun hal tersebut telah diterapkan, namun tetap tidak mengalami penurunan dalam penggunaan alat tangkap yang dilarang atau dengan kata lain penggunaan alat tangkap yang dilarang tersebut belum terbasmi sampai ke akarnya karena alat tangkap yang digunakan nelayan banyak di memodifikasi menjadi semi trawl.

Kerjasama yang telah di bangun selama ini bersifat insidental sehingga perannya sebagai leading sector dalam pencegahan kegiatan illegal fishing di wilayah laut kabupaten aceh barat belum maksimal dilakukan dikarenakan terbatasnya anggaran serta sarana transportasi dalam melakukan patroli secara bersama di perairan kabupaten aceh barat.

\section{Pelarangan penggunaan alat tangkap yang tidak ramah lingkungan}

Strategi berikutnya yang dilakukan oleh lembaga panglima laot kabupaten aceh barat dalam mencegah terjadinya illegal fishing yaitu melakukan sosialisasi kepada nelayan secara langsung maupun melalui lembaga panglima laot lhok ataupun kelompok pengawas yang dibentuk untuk menyampaikan larangan penggunaan alat tangkap ikan yang dilarang seperti pukat harimau/trawl. Berikut disajikan gambar alat tangkap trawl yang dapat dilihat pada gambar 1 dan 2 


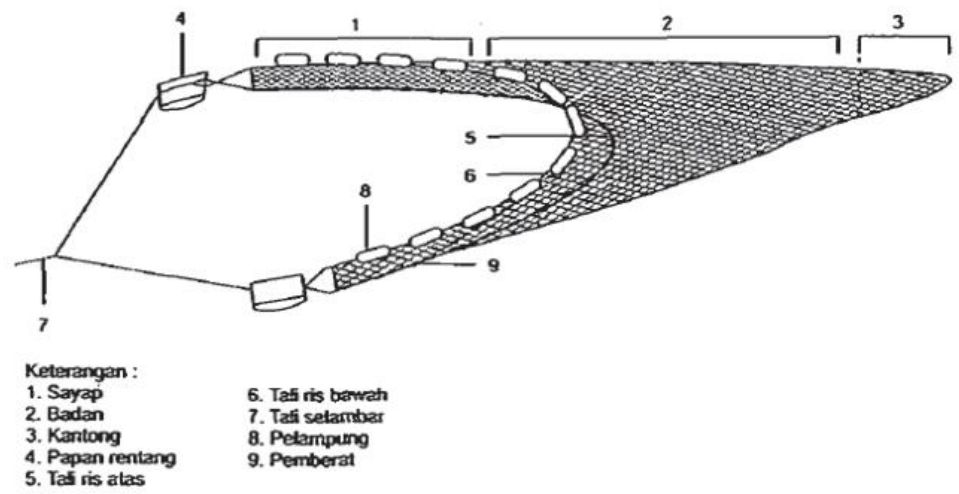

Gambar 1. Sketsa Alat Tangkap Trawl

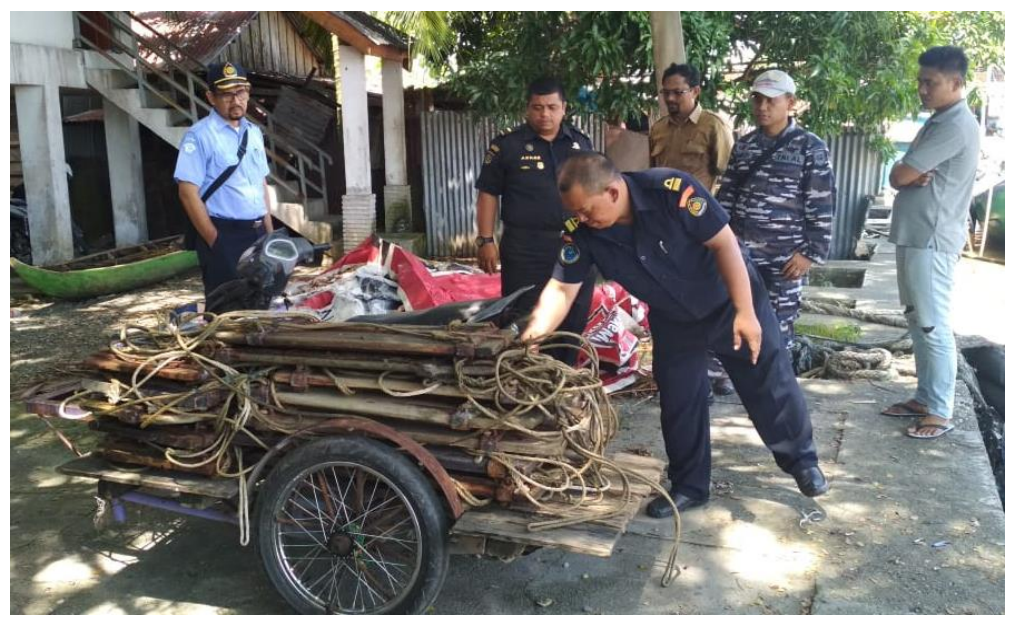

Gambar 2. Alat Tangkap Trawl yang disita panglima laot

Pada gambar 2. merupakan alat tangkap milik nelayan Aceh Barat yang ditangkap oleh panglima laot yang bekerja sama dengan TNI AL. Alat tangkap tersebut disita dan selanjutnya dijatuhkan sanksi kepada nelayan yang melakukan pelanggaran berupa pembakaran alat tangkap secara bersama-sama.

Meskipun sanksi tersebut telah diterapkan selama ini, tetapi sampai sekarang masih belum efektif dalam memberantas penggunaan alat tangkap trawl/semi trawl di kalangan nelayan hal tersebut dikarenakan jika menggunakan alat tangkap trawl maka hasil tangkapan yang diperoleh akan lebih banyak karena sifat trawl ditarik menggunakan mesin dan bersifat tidak selektif sehingga seluruh ukuran ikan akan tertangkap dan bahkan akan merusak biota ikan seperti terumbu karang. Penggunaan alat tangkap trawl di Kabupaten Aceh Barat hanya terdapat di beberapa lhok dan salah satunya di Kecamatan Johan Pahlawan.

Selain problem tentang penggunaan alat tangkap yang tidak ramah lingkungan, problem lainnya yaitu adanya kapal nelayan dari sumatera utara yang melakukan penangkapan ikan di perairan aceh barat dan identitas kepemilikan kapal tersebut diatasnamakan masyarakat nelayan Kabupaten Aceh Barat.

Problematika mengenai penamaan dan operasional kapal tersebut banyak terdapat di Aceh Barat dan sampai sekarang belum ada solusi dalam menyikapi probelematika tersebut. 
Sementara kapal nelayan lokal yang digunakan mencari ikan selama ini berukuran kecil yaitu rata-rata 5 GT yang jika melaut hanya bertahan 2-3 hari, sedangkan kapal nelayan yang dari luar aceh barat tersebut rata-rata berukuran antara 5-15 GT sehingga jika melaut akan mampu bertahan antara 7-10 hari yang memberikan dampak pada banyaknya hasil tangkapan nelayan

\section{SIMPULAN}

Kelembagaan panglima laot belum efektif dalam mencegah illegal fishing di Kabupaten Aceh Barat dikarenakan strategi yang telah buat dan dilakukan selama ini tidak berjalan sebagaimana yang diharapkan. selain itu peran panglima laot hanya fokus pada adat istiadat di kawasan pesisir serta panglima laot hanya sebagai pemberi informasi kepada pemerintah tanpa dibekali dengan sarana dan prasarana yang lengkap, serta masih maraknya penggunaan alat tangkap ikan dengan menggunakan trawl atau semi trawl.

\section{SARAN}

Untuk mewujudkan pemberantasan pencurian ikan secara illegal maka peneliti memberikan beberapa saran:

1. Saran untuk DKP Kabupaten Aceh Barat: Adanya follow up oleh pemerintah dari setiap laporan/atau aduan oleh masyarakat serta perlu dibangunnya POS lapor/jaga/pemantau untuk setiap nelayan yang akan pergi melaut sehingga akan lebih mudah dalam memberantas praktik-praktik illegal fishing. Selain itu DKP Juga melakukan penguatan dan pemberdayaan panglima laot kabupaten aceh barat agar mampu melaksanakan tugas dan fungsinya termasuk untuk pencegahan praktik illegal fishing;

2. Saran untuk panglima laot: melakukan penguatan organisasi secara reguler untuk memastikan berjalannya fungsi organisasi;

3. Saran untuk nelayan: berupaya untuk mengurangi dan bahkan menghilangkan penggunaan alat tangkap trawl dalam melakukan penangkapan ikan guna menjaga kelestarian sumber daya perikanan.

4. Saran untuk perguruan tinggi: secara khusus ditujukan untuk universitas teuku umar yang memiliki visi agro and marine industries untuk terus melakukan upaya-upaya strategis melalui tridharma perguruan tinggi guna menjaga kelestarian sumber daya perikanan serta meningkatkan taraf hidup masyarakat pesisir

\section{REFERENSI}

Aceh Prov, 2014, Potensi di Aceh Mencapai 18 ton Pertahun,http://acehprov. go.id/news/read/2014/05/13/1022/potensi-di-aceh-mencapai-18-ton-pertah un.html, diakses pada tanggal 12 Oktober 2017 pukul 17:58 WIB.

Arikunto, Suharsimi. 2006. Prosedur Penelitian Suatu Pendekatan Praktik. Jakarta: Rineka Cipta.

Burhan Bungin. 2001. Metode Penelitian Kualitatif. Jakarta: PT Rajagrafindo Persada.

Kurniawan Andri. 2008. Faktor-Faktor Yang Mempengaruhi Efektivitas Panglima Laot Dalam Pengelolaan Sumber Daya Alam Laut Di Kota Sabang. Banda Aceh: Jurnal Dinamika Hukum, Vol. 8, No. 3, September 2008.

Qanun Aceh No. 9 Tahun 2008 tentang Pembinaan Kehidupan Adat dan Adat Istiadat dan Qanun Aceh No. 10 tahun 2008 tentang Lembaga Adat. 
Martani, H dan Lubis, S.M. Hari. 1987. Teori Organisasi. Suatu Pendekatan Makro. Jakarta: Pusat Antar Universitas Ilmu-Ilmu Sosial.

Marefanda, N. 2018. Pengawasan sumber daya perikanan sebagai upaya pemberantasan illegal fishing di perairan kabupaten aceh barat. Prosiding seminar nasional FISIP UNSOED Purwokerto 2018.

Moleong, Lexy. 2002. Metodologi Penelitian Kualitatif. Bandung: PT. remaja Rosdakarya

Nikijuluw, V. 2008. Dimensi Sosial Ekonomi Perikanan Ilegal (Blue Water Crime). Jakarta: PT. Pustaka Cidesindo.

Sukmadinata. 2005. Metode Penelitian. Bandung: Remaja Rosdakarya.

S.P. Siagian, Manajemen, Yogyakarta: Liberty, 1978.

Raihan dan Mulyadi. 2017. Kepemimpinan Panglima Laot Dalam Menjaga Kedamaian Antar Nelayan Di TPI Kecamatan Sawang Kabupaten Aceh Selatan.Banda Aceh: Jurnal Manajemen dan Administrasi Islam, al-idarah, Vol. 1, No. 1, Januari-Juni 2017.

Undang-undang No 11 tahun 2006 tentang Pemerintahan Aceh (pasal 98 - 99 dan pasal 162 ayat (2) huruf e), Panglima Laot Aceh, 2009, Penerapan Pola SISWAMAS oleh

Panglima Laot Upaya Mencegah illegal fishing, http ://www.panglimalaotaceh.org/artikel/penerapan-pola-siswasmas-oleh-pangl ima-laotupaya-mencegah-illegal-fishing/, diakses pada tanggal 11 Oktober 2018 pukul 16:36 